\title{
DOWN WITH BRITAIN, AWAY WITH ZIONISM: THE 'CANAANITES' AND 'LOHAMEY HERUT ISRAEL’ BETWEEN TWO ADVERSARIES
}

\begin{abstract}
Roman Vater*
ABSTRACT: The imposition of the British Mandate over Palestine in 1922 put the Zionist leadership between a rock and a hard place, between its declared allegiance to the idea of Jewish sovereignty and the necessity of cooperation with a foreign ruler. Eventually, both Labour and Revisionist Zionism accommodated themselves to the new situation and chose a strategic partnership with the British Empire. However, dissident opinions within the Revisionist movement were voiced by a group known as the Maximalist Revisionists from the early 1930s. This article analyzes the intellectual and political development of two Maximalist Revisionists - Yonatan Ratosh and Israel Eldad - tracing their gradual shift to anti-Zionist positions. Some questions raised include: when does opposition to Zionist politics transform into opposition to Zionist ideology, and what are the implications of such a transition for the Israeli political scene after 1948?
\end{abstract}

\section{Introduction}

The standard narrative of Israel's journey to independence goes generally as follows: when the British military rule in Palestine was replaced in 1922 with a Mandate of which the purpose was to implement the 1917 Balfour Declaration promising support for a Jewish 'national home', the Jewish Yishuv in Palestine gained a powerful protector. In consequence, Zionist politics underwent a serious shift when both the leftist Labour camp, led by David Ben-Gurion (1886-1973), and the rightist Revisionist camp, led by Zeev (Vladimir) Jabotinsky (1880-1940), threw in their lot with Britain. The idea of the 'covenant between the Empire and the Hebrew state' which (temporarily) replaced their demand for a Jewish state with the long-term prospect of bringing the Yishuv to qualitative and quantitative supremacy over the Palestinian Arabs under the wings of the British Empire. As a scholar of the Yishuv, Yehoshua Porat, explains,

[All the Zionist parties] believed that the British Mandate over the Land of Israel must be maintained and that the creation of the new Jewish society will be the result of a gradual process ... While the workers' parties opined that with the help of the proletariat ... it will be possible to develop voluntarily an autonomous society in the Land of Israel, the Revisionist movement stressed the importance of the British-Mandatory political factor: upon it lay the duty of forging political conditions ... which will enable the Zionist movement to advance

\footnotetext{
* PhD candidate, Department of Middle Eastern Studies, University of Manchester. Email: romans.vaters@ postgrad.manchester.ac.uk

${ }^{1}$ Joseph Heller, 'The Zionist Right and National Liberation: from Jabotinsky to Avraham Stern', Israel Affairs 1:3 (1995): 95
} 
unhindered the process of immigration to the land and its construction, until the Jewish Yishuv becomes a majority. ${ }^{2}$

Hence, the difference between the Labour and Revisionist Zionists was more of a tactical rather than strategic character: both treated Great Britain as an ally, though maintaining a balance of interests between it and the Yishuv was a wearisome task. When conflict arose between the Mandate and the Yishuv authorities, the latter usually chose diplomatic methods to push Britain to cooperate. Only when the Biltmore Platform, which defined explicitly the aim of Zionism as the establishment of a 'Jewish commonwealth' (a sovereign state, by any other name) in Palestine, was adopted in May $1942^{3}$ did the Zionist leadership begin to move away from the idea of the Yishuv's strategic dependence on Britain. By that time the Yishuv had grown in strength and numbers, and Hitler's persecution of the Jews had furnished the Zionist leadership with a powerful argument for Jewish independence. Using diplomatic and warfare tactics, the State of Israel was created in 1948.

Yet this narrative overlooks alternative standpoints on the Zionist-British relationship which rose within the ranks of the Revisionist movement back in the 1930s. They were enunciated chiefly in an informal circle of so-called 'Maximalist Revisionists'. This group of radical right-wing activists, disappointed with what it perceived as a lack of sufficient protection and support by the British for the Yishuv (especially after the Arab-Jewish clashes of 1929), came to doubt Britain's role as an ally. Their premise was based on two assumptions: that the Hebrew-speaking Yishuv in Palestine had become a native society, therefore deserving of self-determination instead of colonial protection; and that no actual alliance of interests existed between the Zionist movement and the British Empire. They insisted on presenting Britain with an ultimatum: either it would side wholeheartedly with the Zionist enterprise or the Yishuv would seek to replace the British Mandate with another protector (such as fascist Italy, to which the Maximalists were particularly sympathetic, as it represented a socio-political option close to their outlook) while simultaneously conducting a guerrilla war against it, modelled upon the Irish Sinn Féin. When the British Peel Commission, in 1937, recommended the creation of a Jewish state in a small part of Palestine (annexing the remainder of the territory to Transjordan and leaving the corridor leading from the Jaffa port to Jerusalem under British protection), the abolishment of the Mandate became for the first time a real option. With the British Empire questioning its own right and ability to rule Palestine, the Maximalists began drawing up detailed political plans for the day after the Mandate. Furthermore, they accused Zionist leadership (mainly Labour, but tacitly their own as well) of acting against the vital interests of the Jewish people and the Yishuv by clinging to the strategic alliance with the British Empire. The Maximalists approved of acts of terrorism directed at the

\footnotetext{
2 Yehoshua Porat, Shelah veet beyado: Sipur Khayav shel Uriel Shelah (Yonatan Ratosh) (Tel Aviv: Makhbarot lesifrut, 1989), 41. All translations from Hebrew, unless stated otherwise, are my own. See also Nathan Yalin-Mor, Lohamey Herut Israel: Anashim, Re'ayonot, 'Alilot (Jerusalem: Shikmona, 1975), 241.

${ }^{3}$ For the Biltmore Platform text, see http://www.jewishvirtuallibrary.org/jsource/History/biltmore.html. For the historical circumstances surrounding its formulation, see David Arnow, 'The Holocaust and the Birth of Israel', Journal of Israeli History: Politics, Society, Culture 15:3 (1994): 261-2, 264-5; Evyatar Friesel, 'On the Myth of the Connection between the Holocaust and the Creation of Israel', Israel Affairs 14:3 (2008): 449-50.
} 
British and, having renounced democracy, they called for an overthrow by force of Haim Weitzman, the president of the World Zionist Organization. ${ }^{4}$

By questioning the principal political paradigm of post-1922 Zionism, including that of their own Revisionist movement, the Maximalists came close to the limits of contemporary Zionist consensus; while most of them did not eventually break those limits, there were some who did. The aim of this article is to map out the process by which the Maximalist opposition to Zionist policy evolved in certain cases to oppose Zionist ideology. What was the point at which some Maximalists realized that the alliance with Britain was, for Zionism, not simply a temporary tactic but an essential ideological component? Finally, this article shall attempt to assess how Maximalists re-evaluated Zionism, and how their initial Zionist zealousness morphed into staunch anti-Zionism.

In order to analyze this, I have chosen to concentrate on sources that are representative of the aforementioned transformation. This article will offer a study of several works by two prominent political thinkers of the Yishuv, whose thought was profoundly shaped by Maximalist Revisionism. One is Uriel Shelah, better known under the pseudonym Yonatan Ratosh (born Heilperin, 1908-1981), one of the most prominent 20th century Hebrew poets, and also the figure most closely associated with the anti-Zionist movement known as the 'Young Hebrews', but more often referred to as the 'Canaanites'. The other is Israel Scheib (Eldad, 1910-1996), who is remembered for his renditions of Nietzsche's works into Hebrew, and who also co-headed the LEHI (Lohamey Herut Israel, 'Fighters for the freedom of Israel's) underground movement from 1943. Beginning in the 1930s, both men expressed in the Revisionist press their dissatisfaction with the British rule, which later developed into a criticism of the entire Zionist movement and finally a rejection of the Zionist ideology, at least as it was professed by the contemporary Zionist leadership. It is the purpose of this article to follow their path from anti-Britishness to anti-Zionism, that is, to try and see how a particular political standpoint leads to a revision of basic values, by juxtaposing the two thinkers' intellectual development. It will be shown that Yonatan Ratosh broke the confines of Zionism once he adopted a historiographic 'commemorative narrative' ${ }^{6}$ which contradicted the Zionist historiographic base and made the Zionist cultural-political platform untenable. Israel Eldad, contrary to Ratosh, would commit himself to a radical redefinition of the Zionist ideology without undermining its historico-philosophical base. Thus, whereas Ratosh eventually adopted an alternative national idea, which regarded Zionism as a foreign and hostile monolith, Eldad renegotiated Zionism to such extent that he excluded from its limits all trends and currents except his own. It will be demonstrated that these different intellectual starting

\footnotetext{
${ }^{4}$ James S. Diamond, Homeland or Holy Land? The 'Canaanite' Critique of Israel (Bloomington, Indianapolis: Indiana University Press, 1986), 28-30; Eran Kaplan, The Jewish Radical Right: Revisionist Zionism and its Ideological Legacy (Madison: University of Wisconsin Press, 2005), 148-58; Porat, Shelah veet beyado, 42-54, 66-7. A fresh though not entirely convincing analysis of Maximalist Revisionism is offered by Dan Tamir. See Dan Tamir, "Dictate more, for we should obey your orders!" Cult of the Leader in Inter-War Hebrew Fascism', Politics, Religion \& Ideology 14:4 (2013), 449-67; Dan Tamir, 'Some Thoughts about Hebrew Fascism in Inter-War Palestine', Zeitschrift für Religionsund Geistesgeschichte, 63:4 (2011), 364-81.

${ }^{5}$ In this context, 'Israel' refers not to the state, but to the entire Jewish nation, conceptualized, as we shall see below, in metahistorical terms.

${ }^{6}$ Yael Zerubavel defines 'commemorative narrative' as 'a broader view of history, a basic "story line" that is culturally constructed and provides the group members with a general notion of their shared past'. Yael Zerubavel, Recovered Roots: Collective Memory and the Making of Israeli National Tradition (Chicago, London: The University of Chicago Press, 1995), 6.
} 
points resulted in a development of diametrically opposed political positions in post-1948 Israel.

The works by Yonatan Ratosh scrutinized below are his series of articles published in 1937 under the headline We Aspire to Power, while he was still a devout Zionist, and the essay 'The Opening Discourse', printed in 1944 as a manifest of his new anti-Zionist 'Canaanite' stance. Eldad's works analyzed below are his series of programmatic articles 'Foundation stones', which he published while still active in the LEHI underground in 1943, and several other pieces which he wrote after Israel's foundation, including two interviews given shortly before his death in 1996. The comparative analysis of these works will allow us to measure the extent of both men's intellectual transformation. It will be observed that while Ratosh changed his views profoundly over a short period of time, Eldad remained more consistent in his opinions from the 1940s to the 1990s, modifying them only slightly after the establishment of Israel.

\section{Yonatan Ratosh - from Maximalism to Hebrew Nationalism}

In order to adequately understand the transformation of Yonatan Ratosh from a radical Zionist to a radical anti-Zionist we must map the intellectual context in which he acted. Ratosh, who was involved since high-school with Revisionist activity, came soon under the influence of Maximalist Revisionists. They were especially appealing to him due to the fact that they used the Yishuv's ostensible nativeness to legitimate anti-British agitation. As Ratosh explained in an autobiographic article: 'Since my youth ... I conceived the British as a foreign power, therefore entirely superfluous', since 'if ... for the elderly who came from Eastern Europe the British rule was a progressive mandatory rule by the liberal and enlightened Great Britain, for me it was naturally a foreign rule'. ${ }^{7}$ Ratosh, who grew up in a Hebrew-speaking home in Warsaw and Odessa, and lived in Palestine from age 11, perceived the British presence in the eyes of a self-declared native, framing it within a wider question of his own identity as a Palestinian Hebrew/Jew. Thus, while for the Maximalist Revisionists the British presence in Palestine (and Zionist cooperation with it) was primarily a political-strategic issue, for Ratosh it was also a matter of native sentiment.

Ratosh found himself attracted to Maximalism due to his belief that it expressed the 'true' ideology of Jabotinskian Revisionism, which mainstream Revisionists avoided formulating explicitly due to tactical considerations. Yet disappointment soon followed:

I remember well how I was healed from this illusion. It was in Jerusalem, at the end of the first week of April, 1934 ... One of the Revisionist luminaries in the country [Palestine], a Russian intelligent, like most of the party's leadership, wanted to have an article printed in the newspaper [Hayarden, which Ratosh co-edited] ... He explained very eloquently that the 'Activists' ... were merely a marginal phenomenon, while the [Revisionist] Party line was actually the 'Ten-Year Plan'. The Plan envisaged a demand from Britain to introduce a settler 'colonizing regime' to facilitate through land allocation to Hebrew settlement and an encouraging taxation system the creation of a Jewish majority in the Land within a decade, and only then, at the end of the decade, when the hoped-for Hebrew majority will become reality in

\footnotetext{
${ }^{7}$ Yonatan Ratosh, 'Hakdama', in Yonatan Ratosh, Reshit Hayamim: Ptikhot 'Ivriyot (Tel Aviv: Hadar, 1982), 8, 20 (emphasis mine).
} 
the Land, to grant it independence, as stipulated in the Mandate ... I became convinced that his words ... truly represented the line of the Party and its leader ... I found [in this article] a corroboration of my growing doubts regarding this movement. ${ }^{8}$

As James Diamond puts it, 'Ratosh's original suspicion of the entire Zionist enterprise now intensified: Revisionism, too, was part of what he saw as a collusion of European Diaspora Jews with European non-Jews to decide the fate of Palestinian Jews'. ${ }^{9}$

However, the stormy political dynamic of the 1930s gave Ratosh an opportunity to agitate for his views still within the Revisionist movement. In early July 1937 the Peel Commission published its report, which Ratosh saw as a geopolitical turning point, both for Britain and for Zionism, since mandatory rule became contestable (by explicit admission of the British authorities themselves). From July to December 1937 he published a series of articles in Hayarden (reprinted the following year in an expanded version in a booklet titled We Aspire to Power ${ }^{10}$ ), in which he urged the Zionist movement to press for an immediate transfer of sovereignty over Palestine to the Yishuv, in accordance with the original principles of the Mandate and the Balfour Declaration. He argued that

The National Movement [the Revisionists] must adopt the first rule of political Zionism as its basic primary rule. When the Balfour Declaration was delivered, Zangwill demanded that the rule should be transferred to the Jews at once. We must revert to this demand ... We must claim it right now. ${ }^{11}$

And furthermore:

The Hebrew rule is the only rule which can implement the aims of the Mandate wholly and sincerely, [that is] to ease the Hebrew aliya and Hebrew settlement. ${ }^{12}$

Yehoshua Porat explains that such a demand, 'which indeed constituted a return to the notions promoted by Herzl, Nordau and Zangwill, had been abandoned by that time by the Revisionist movement, and currently seemed too strong and revolutionary in light of its present-day policy'. ${ }^{13}$ Ratosh, who was perfectly aware of this, dedicated a lot of space to a harsh criticism of the Revisionist movement, which for him became similar to Labour Zionism by legitimizing the British presence in Palestine. Ratosh argued that by adhering to diplomatic policy vis-à-vis the British, the Zionist leadership effectively gave up its claim to Palestine:

The slogan of the [Zionist political] war is not freedom, but pressure for negotiations ... We do not claim the chair [of King David, occupied by the foreigner]. We only ask that he who occupies it improves his rule, fulfils our wishes. ${ }^{14}$

${ }^{8}$ Ibid., 20-1.

9 Diamond, Homeland or Holy Land?, 30.

${ }^{10}$ Reprinted in Ratosh, Reshit hayamim, 42-59.

${ }^{11}$ Ibid., 44-5.

${ }^{12}$ Ibid., 59. Note the usage of the adjective 'Hebrew', which Ratosh, still in accordance with the pre-1948 Zionist practice, applies indiscriminately to Palestine-born Hebrew-speakers and Jews immigrating to Palestine.

${ }_{13}$ Porat, Shelah veet beyado, 99.

${ }_{14}$ Ratosh, Reshit hayamim, 44. 
We, who do not demand the power, but a foreign patronage ... admit that we are not capable of ruling the Land. ${ }^{15}$

[The Zionist movement] does not conclude that [the mandatory] regime is illegal and cannot solve the Jewish question, it does not want to replace it with a Zionist regime ... It only asks from the present regime to replace its executors and to do what it refuses to do from its first day till today. The Zionist movement does not define the British administration in the Land of Israel as enemy; to the contrary, it sees in Britain the only faithful and desired ally. ${ }^{16}$

Despite Ratosh's dissatisfaction with both Zionist streams, his rhetoric still conformed to the Zionist paradigm, as he himself admitted in hindsight. ${ }^{17}$ The distinction that he makes between Jews and Hebrews is in accordance with Zionist principles (that is, a Hebrew means a 'better' Jew); he refers to the Diaspora as the potential rearguard for the Zionist thrust in Palestine; finally, he makes clear that the final end of his plan is to implement the Zionist objective and the Balfour Declaration. He does not rebel (yet) against the essence of Zionism, only against its leadership which supposedly betrayed its founding principles. Ratosh thus posits himself as the speaker of the younger Hebrew generation in Palestine, ready to deploy grassroots pressure upon the opportunist and weak-spirited 'elders'. We can therefore define Ratosh's 1937 standpoint as a 'fundamentalist' Zionism, calling for the return to the ideology's core values. ${ }^{18}$

Despite its overall adherence to Zionist orthodoxy, We Aspire to Power was subversive enough to cause consternation within the ranks of the Revisionist movement. The Revisionist youth, both in Palestine and abroad, is reported to have welcomed Ratosh's booklet enthusiastically, but the Revisionist senior ranks treated Ratosh as an over-zealous nuisance. Ratosh attempted to advance his program at the convention of the (Revisionist) New Zionist Organization in Prague in early 1938, but his propositions were voted off the agenda (only the Polish delegate, Menachem Begin, and most of the Palestine delegation objected). Ratosh held two personal meetings with Zeev Jabotinsky, also to no avail. He later described Jabotinsky as 'an old man ... whose world was totally and fundamentally different from mine', ${ }^{19}$ accusing him of ignorance in global geopolitics. Ratosh, like many other young Revisionists, was also indignant with Jabotinsky when he supported at the beginning of the Palestinian Arab Revolt in 1936 the 'restraint' policy promulgated by the Labour Zionist leadership. As a result, Ratosh wrote years later, he was removed from the editorial board of Hayarden, ${ }^{20}$ though Porat questions this particular claim. The latter shows that Ratosh continued to publish articles in this newspaper after 1937 and that there was no abrupt termination of his publications, but rather a gradual decline. Porat admits that he is unsure of the exact cause, but attributes it quite reasonably to Ratosh's growing radicalization and remoteness from Zionism. ${ }^{21}$

${ }^{15}$ Ibid., 49.

${ }^{16}$ Ibid., 58.

${ }^{17}$ Ratosh, 'Hakdama', 15. See also editor's footnote in Ratosh, Reshit hayamim, 42.

${ }_{18}^{18}$ For more on We Aspire to Power and its context, see Diamond, Homeland or Holy Land?, 31-3; Porat, Shelah veet beyado, 70-2, 85-9, 97-104, 108; Ratosh, 'Hakdama', 15-24.

${ }_{19}$ Ratosh, 'Hakdama', 16, 17.

${ }^{20}$ Ibid., 15.

${ }^{21}$ Porat, Shelah veet beyado, 103-18. 
The relatively short time-span of 1938-1939, which Ratosh spent in Paris, is a key period in his intellectual formation, since it was then that he finally crossed the line between doubting Zionist politics to doubting Zionist ideology. He came to perceive the Revisionist movement as essentially identical with Labour Zionism (to which Ratosh admitted to have felt aversion since high-school), and the rejection of his propositions at the Prague convention, as Diamond sees it, 'reinforced his perception that Zionism was as foreign an entity as the British'.22 Ratosh recalled that what he saw in Prague was 'the [Revisionist movement] in its native habitat ... - the Diaspora. For me it was a first direct contact with the Diaspora, which forced me to reevaluate my own Hebrew world'.23 Having realized the depth of the abyss between his own Palestinian society (or its rather small section which used Hebrew on a daily basis and regarded itself as indigenous to the Land) and Diaspora Jewry, he drew a sharp socio-cultural distinction between the two, defining the former as a territorial-linguistic nation and the latter as a cosmopolitan faithcommunity with no authentic aspiration for national sovereignty. In his last articles in Hayarden, Ratosh began advancing the idea that the current troubles of the Diaspora in the looming shade of Hitlerism should not bother the Revisionist movement; moreover, he began referring to the 'Hebrew golden age' before the emergence of monotheistic Judaism as the cultural foundation of Hebrew nationalism. ${ }^{24}$

The adoption of these ideas should be attributed to Ratosh's acquaintance with another ex-Revisionist, Adya Gur Horon (born Adolphe Gourevitch, 1907-1972), who, as a student of the ancient Near East and Semitic philology at the Sorbonne, took part in the deciphering of the Ugarit epic poetry discovered in Syria in 1929. This inspired him to portray the pagan Hebrews as empire- and civilization-builders in the ancient Levant and the Mediterranean, whose demise came as a result of the dissemination and adoption of Judaism. Horon thus formulated a historiography of the ancient Hebrews which radically differed from the standard Jewish-Zionist historiography, with its strong messianic elements and the stress on the Jewish Diaspora sufferings and longing for redemption. ${ }^{25}$ Subsequently, Horon shared his historical findings with Ratosh, who used them to construct a new political ideology, one that would aspire to recreate the national values and potency of the Hebrew 'golden age' and discard the historical baggage of Judaism and Diaspora as essentially non-nationalist. ${ }^{26}$ When Ratosh returned from Paris to Palestine in September 1939, he arrived as a convert to anti-Zionism, espousing the 'Canaanite' ideology, which must be regarded as basically different from Zionism due to the dissimilar historiographic sources of both ideologies, since it should be argued that different visions of the past regarding a particular community would necessarily lead to a formulation of different visions of the future for the same community - in this case, the Yishuv. It can be argued furthermore that if Ratosh's opposition to the Revisionist and Zionist leadership

22 Diamond, Homeland or Holy Land?, 33.

${ }^{23}$ Porat, Shelah veet beyado, 114. See also Diamond, Homeland or Holy Land?, 32-3, 147 (n. 41); Porat, Shelah veet beyado, 80, 96-7, 103-14; Ratosh, 'Hakdama', 15-22. Ratosh mentions sardonically that most of the delegates at the Prague convention did not understand what he was actually saying, since he spoke Hebrew (ibid., 19).

${ }^{24}$ Porat, Shelah veet beyado, 111.

${ }^{25}$ For Horon's historiography, see Adolphe G. Horon, 'Canaan and the Aegean Sea: Greco-Phoenician Origins Reviewed', Diogenes 58 (1967): 37-61; A. G. Horon, Eretz-Hakedem: Madrikh Histori umdini lamizrakh Hakarov (Tel Aviv: Hermon, 1970); A. G. Horon, Kedem vaerev: Knaan - Toldot Eretz ha'ivrim (Tel Aviv: Dvir, 2000).

${ }_{26}$ On Horon-Ratosh intellectual tandem of 1938-39, see Diamond, Homeland or Holy Land?, 34-8; Porat, Shelah veet beyado, 119-57; Ratosh, 'Hakdama', 12-15. On the 'Canaanite' idea in general, see Diamond, Homeland or Holy Land?; Klaus Hofmann, 'Canaanism', Middle Eastern Studies 47:2 (March 2011): 273-94. 
before his acquaintance with Horon was limited to a political disagreement, his post-1939 anti-Zionism was grounded in a strong intellectual base.

The most detailed exposure of the tenets of 'Canaanism' is the 1944 manifesto 'The Opening Discourse'. ${ }^{27}$ Diamond is only slightly exaggerating when describing it as 'one of the most remarkable and important documents of Jewish intellectual history in [the $20^{\text {th }}$ ] century',28 though the adjective Jewish is highly doubtful methodologically, since at the core of 'Canaanism' lies a firm dichotomy between Jews as an ethno-denomination and Hebrews as a nation, and Ratosh surely would have been seriously offended if he had been called a Jewish intellectual. ${ }^{29}$ 'The Opening Discourse' lays bare the way which Ratosh went from 'fundamentalist' Zionism to all-out rejection of Zionism as a Jewish ideology formed in the Diaspora and hostile to the Hebrew nation-creation which he believed was taking place in Palestine as a non-Jewish phenomenon. By the time Ratosh wrote 'The Opening Discourse' he came to regard Zionism as a Jewish imitation of Gentile nationalism:

The Zionists were Jews who went out to the culture of the Gentiles because of an inability to find satisfaction in Judaism, but not because of the ability or the desire to take leave of it. Or perhaps they did seek to leave it but couldn't overcome the obstacles in doing so. So they sought to define Judaism for their purposes as a polity, as a nation among the nations in which they lived, in a world that is based on the principle of nationalism, as a ... substitute ... for the nationalism of the Gentiles which they found lacking in themselves; in other words [the Jewish Zionists were] bereft of any grounding in society, uprooted in a world of nations. Zionism from the outset came into being as a substitute for this need. It was created out of a vacuum, in the emptiness of the Jewish heart, in order to fill it with a substitute, in order to provide the possibility to continue to live as a Jew among the Gentiles. ${ }^{30}$

Ratosh lists the founding principles of Zionism: 1) the Jews are a people, 2) that desires the Land of Israel as its homeland, 3) and for that aim have set up a movement of national liberation 4) which has caused the Jewish settlement in Palestine, thereby solving the 'Jewish question', ${ }^{31}$ and then proceeds to refute them one by one:

The Jews are not a nation and never were. They are not a nation but a faith-community [literally, 'edah] whose existence is in the Dispersion and whose homeland is the Dispersion. This Jewish faith-community has a Holy Land as do many faith-communities. But it has no homeland, nor does it need one, nor does it want one, neither this land nor any other land. A faith-community by its very nature does not have the capacity to establish a national liberation movement ... Zionism, as a Jewish phenomenon, as a phenomenon within a faith-community, can absolutely never, from its beginning to any form it will assume in the future, be a movement of national liberation or a national movement at all ... The Hebrews in Palestine are in no way the direct result of Zionism. ${ }^{32}$

\footnotetext{
27 Reprinted in Ratosh, Reshit hayamim, 149-203.

28 Diamond, Homeland or Holy Land?, 51.

${ }^{29}$ It is not the author's intention to imply that we should accept 'Canaanite' assertions at face value, only to suggest that the uncritical annexation of 'Canaanism' to Jewish intellectual history betrays insensitivity to its basic principles.

${ }_{30}$ Ratosh, Reshit hayamim, 179, cited in Diamond, Homeland or Holy Land?, 72-3.

31 Ratosh, Reshit hayamim, 176; Diamond, Homeland or Holy Land?, 55.

32 Ratosh, Reshit hayamim, 178, cited in Diamond, Homeland or Holy Land?, 56.
} 
We can infer from the above some of 'Canaanism's' central assumptions: that Zionism, which the 'Canaanites' regarded as a surrogate for the community-forging function previously performed by Judaism, was inherently false and therefore anything it endeavoured in Palestine, even if helpful in the short-term, was inevitably 'ill from the start'; 33 that Zionism was part and parcel of Jewish history, being a continuation rather than a break with it; ${ }^{34}$ that it was inimically hostile to the Hebrew national consolidation and therefore must be fought against; that nation and faith-community were opposites, since 'family and nation, biology and sociology, are two entirely different essences'; 35 finally, that the determinist law of history was that the [Hebrew] nation must supersede the [Jewish] denomination, since in the modern world communities give way to nations. ${ }^{36}$ By identifying Zionism with Diaspora Judaism, Ratosh essentially turns the Zionist weapon (its anti-Diaspora rhetoric, the so-called 'shlilat hagalut', or 'the negation of Exile') against Zionism itself.

What is particularly interesting is that in 'The Opening Discourse' Ratosh abandons almost entirely his We Aspire to Power theses. Though he mentions 'the eternal Jew Vladimir Jabotinsky' who opposed an armed retaliation to the Arab Rebellion in 1936, ${ }^{37}$ he makes no call for the expulsion of the British and does not demand the immediate establishment of a Hebrew state. Moreover, he accuses the anti-British underground organizations such as the ETZEL (the Revisionist-associated 'Irgun Tzvai Leumi', the 'National Military Organization', whose supreme commander was Jabotinsky) or the LEHI of being 'an opposition preserving the existing order' ${ }^{38}$ Porat regards this as a severe weakness of the 'Canaanite' founding manifest and remarks that some contemporaries even believed Ratosh had become a British agent (nothing could be farther from the truth, of course), but he observes that at this stage Ratosh saw no sense in an armed struggle against the British under Zionist banners'39 ('The Opening Discourse' makes several sarcastic references, in Ratosh's idiosyncratic style, to the Jewish underground organizations, whose activity, ironically, was partly inspired by Ratosh's own We Aspire to Power ${ }^{40}$ ). 'The Opening Discourse' is above all a piece of ideological education; Ratosh

\footnotetext{
${ }^{33}$ Ratosh, Reshit hayamim, 168.

34 This unanimous conclusion effectively did away with Zionism's severest dilemma: whether it had its sources in the Jewish historical legacy and thus constituted a natural continuation of Jewish history or was it a rebellion against the Jewish past, ushering in a revolutionary historical phase. See Diamond, Homeland or Holy Land?, 9-23; Gerschom Scholem, 'Hatziyonut - Dialektika shel Retzifut umered', in Ein Shaananim betziyon: Sikhot al Mekhir hatziyonut, ed. Ehud Ben-Ezer (Tel Aviv: Am Oved, 1986), 287-317; David Vital, 'Zionism as Revolution? Zionism as Rebellion?', Modern Judaism 18 (1998), 205-15.

${ }^{35}$ Ratosh, Reshit hayamim, 181.

${ }^{36}$ For further analysis of 'The Opening Discourse', see Diamond, Homeland or Holy Land?, 49-75; Porat, Shelah veet beyado, 194-203.

${ }_{37}$ Ratosh, Reshit hayamim, 163.

${ }^{38}$ Ibid., 197.

${ }^{39}$ Porat, Shelah veet beyado, 198-200.

${ }^{40}$ For instance: 'A Hebrew youngster, who imagines that the road to liberation leads through a dominant terroristic organization and yearns to attack a British policeman or a commissioner, is required to display excitement ... with a speech by some Jewish boy called Spiegermann, whose ailment is the Jewish sense of inferiority ... And to his younger brother [this Hebrew youngster] is obliged to teach diligently - using a special edition for teenagers published by the LEHI - a literary work of imagination and trepidation regarding the significant moods of various Jewish types of defectors from the Polish army [an allusion to the ETZEL leader Menachem Begin, who reached Palestine in 1942 as a soldier in the Polish army formed in the USSR by general Władysław Anders and was in fact legally discharged from service. See Yalin-Mor, Lohamey Herut Israel, 146, 175], whereas they are assimilationists, and Zionists, and revolutionary Zionists ... A Hebrew youngster, who wishes to attack government centres, to blow-up huge buildings and to fight an ETZEL gun-fight in the night, is forced to make the demand for [Hebrew] power a kind of additional comment to heaps of Jewish demands'. Ratosh, Reshit hayamim, 163; 'While the "Israel-liberation-
} 
believed that only when the Hebrew youth in Palestine is won over to 'Canaanism', not only the British but also the Zionists will be defeated. ${ }^{41}$ This redefinition of priorities regarding the chief enemy's identity is therefore perfectly plausible: having realized that his main front will be against the Zionists, the British became of secondary importance for Ratosh. Many years later he admitted to holding a grudge against them for having occupied so much of his time and intellectual effort. ${ }^{42}$

\section{Israel Eldad - from Maximalism to Redemption}

Since Israel Eldad grew to be LEHI's foremost intellectual, we must examine his writings in order to assess to what extent LEHI was an 'anti-Zionist' movement. In 1941 Avraham Stern, the movement's founder, declared that Zionism, incapable to oppose the British mandatory power and unable to save European Jews from Hitler, had rendered itself obsolete and must clear the stage for a genuine Hebrew liberation movement, which, as Yalin-Mor interprets it, should become an 'anti-thesis' for Zionism. ${ }^{43}$ Ratosh's influence on Stern is readily observable here, as well as on Eldad, though it seems to be limited to his pre-'Canaanite' stage, as the following words by Eldad, published in 1943, testify:

The Balfour Declaration and the Mandate are unlawful documents, both legally and morally, but above all because we, the sole owners of this land, reject the legitimacy of these documents ... This is the legal, moral, just situation. The factual situation is that the Land of Israel is being forcibly ruled by a foreign occupant ... We do not acknowledge their declarations and their mandates, neither do we look for better mandators nor do we inquire into the implementation of particular paragraphs. ${ }^{44}$

Until now Zionism has acknowledged England's right to rule here, 'consecrated' either by the 'Declaration' or the 'Mandate' ... He who restricts himself to a war against the 'White Paper' admits England's general right to be the lord here. He who opposes a particular law acknowledges the lawgiver's principal right to legislate, asking only for a better law. We reject this right ... He who thinks that he can defeat the occupant by new settlements - let him build new settlements. He who thinks that he will manage by congress resolutions - let him do so. We

fighters" [LEHI] cherish the names of the excellent fathers in the lauded ghetto and put out leaflets strumming on Jewish strings ... yet after all of this, and with all of this, following our first publication, they will make sure to put in their brochures Hebrew where they mean Jew and title their leaflets Hebrews in the homeland, as if there can be Hebrews elsewhere, - we shall know then and shall announce that these people are lying to themselves, to us, and to the whole Hebrew youth' (ibid., 170 [emphases in the original]).

${ }^{41}$ LEHI co-chief Nathan Yalin-Mor relates that when he asked Ratosh what will happen when the Hebrew youth internalizes his worldview, Ratosh declared with a smile that all other problems will then be solved easily, as if by themselves. Yalin-Mor, Lohamey Herut Israel, 147. Israeli author Amos Keinan, who joined the LEHI under the influence of 'Canaanite' ideas, recalled that he was told that the Hebrew youth shall be consolidated in the liberation war (implying that Ratosh's 'Committee for the consolidation of the Hebrew youth' was a band of good-for-nothing prattlers). Amos Keinan, 'Vehaknaani az baaretz', Proza 17-18 August-September 1977, 4; Yalin-Mor, Lohamey Herut Israel, 363. Israel Eldad also treated Ratosh's activity scornfully: 'It is possible that the youngsters who used to sit with Ratosh in coffee-houses referred among themselves to the British in strong terms .... Yonatan Ratosh, Sifrut Yehudit balashon haivrit: Ptikhot bevikoret uviv'ayot halashon (Tel Aviv: Hadar, 1982), 178.

42 Ratosh, 'Hakdama', 8, 30.

${ }^{43}$ Yalin-Mor, Lohamey Herut Israel, 76. Similarly, Yalin-Mor stated in a LEHI underground publication that the 'Hebrew freedom movement' was not identical to Zionism, which was 'an ambiguous creature - between the occupant and a liberation movement ... [including] both Weitzman and Jabotinsky' (ibid., 126).

${ }^{44}$ Israel Eldad, 'Avnei Yesod', in Tziyonut: Pulmus ben Zmanenu - Gishot Mekhkariyot veideologiyot, eds. Avi Bareli and Pinchas Ginossar (Sde Boker: Ben-Gurion University, 1996), 458. 
do not believe in this. We believe that settlements and congresses can be helpful for the war, but the war is essentially different ... to demonstrate that the ruler here is the occupant and treat him as an occupant. ${ }^{45}$

We can see in this passage that Eldad moves quite smoothly from anti-British rhetoric to an attack on the Zionist establishment. Although he accepted in an interview given late in life the assessment of the LEHI as a non-Zionist movement, ${ }^{46}$ Eldad hastened to refine it according to his own particular conception of Zionism. Unlike Ratosh after 1939, Eldad did not question the fundamentals of Zionism; rather, he conceptualized them according to his own particular philosophy of history, which differed enough from the customary Zionist interpretation of Jewish history to warrant him the title of 'anti-Zionist', as long as the Zionist movement was dominated by its mainstream, whether of the Labour or the Revisionist kind.

Eldad saw Zionism as primarily a messianic movement, of which the historical purpose was to bring redemption to the Jewish people by gathering all the exiles in a 'Kingdom of Israel' located within the biblical borders of the Promised Land. Eldad's political messianism employs mundane tools to achieve political ends that are then bestowed with a metaphysical and metahistorical quality. His Messiah is not a personal agent of redemption but a historically determined teleology: 'if we speak here of a Jewish messianic vision, we do not refer to its ... Jewish distortion as a vision of universal redemption but to its plain meaning as the Nation's Redemption in the Kingdom of the House of David ... the vision of redemption is a realistic process with the help of heavens'. ${ }^{47}$ Eldad therefore redefines Judaism to suit his perception of its 'actual' essence ${ }^{48}$ and subscribes to a deterministic philosophy of history which represents what he believes to be the 'stable' laws of Jewish history:

The law of the Jewish history is ... the law of stately greatness which will accompany the redemption. The justification for this stately greatness is the spiritual power and the internal spiritual religious and moral purpose which will require [the establishment of] the material Kingdom of Israel ... that will stretch from the Euphrates to the Nile spelling awe all over the peoples around and being materially rich ... This is the law of our history, being the only alternative for the dispersion which is punishment and disaster. 49

With respect to the Diaspora, Eldad has merely the following to say: 'Jew-hatred is the law, the desire to obliterate the Jewish people is the ever-standing desire in all countries, faiths, peoples and regimes ... any golden age of Jewish equality in any of the Diaspora countries

\footnotetext{
${ }^{45}$ Ibid., 461 (emphasis in the original).

${ }^{46}$ An interview with Israel Eldad (hereinafter: Eldad interview), in Bareli and Ginossar, Tziyonut: Pulmus ben Zmanenu, 438 .

${ }^{47}$ Israel Eldad, 'Medinat Israel kerosh-gesher lemalkhut Israel', Sulam 10:1 (1958): 12 (emphasis mine).

${ }^{48}$ Despite the central role Judaism played in his worldview and the religious education he received in his youth, Eldad was never a strictly observant person. See Israel Eldad, "Yemin" u“smol” batziyonut', interview by Michael Sashar, Kivunim 1:38, new series (March 1990), 115-6. He preferred to treat Judaism as custody of what he perceived to be the Jewish national values, distinguishing between its so-called 'internal' essence and the 'external' shell (by which he meant the Halakhic legal code). A similar view of Judaism was espoused by Zeev Jabotinsky. See Raphaella Bilski Ben-Hur, Kol Yakhid Hu Melekh: hamakhshava hakhevratit vehamdinit shel Zeev Jabotinsky (Tel Aviv: Dvir, 1988), 162-3, 174-7, 198-201; Jan Zouplna, 'The Evolution of a Concept: The Relationship between State and Religion in the Thought of Vladimir Jabotinsky, 1919-1940', Journal of Modern Jewish Studies 4:1 (2005), 13-31.

${ }^{49}$ Eldad, 'Medinat Israel', 13 (emphases in the original).
} 
is but $\ldots$ the exception confirming the rule' ${ }^{50}$ Zionism according to Eldad is a movement springing from these two complementary laws of Jewish history, whose dialectic will result in the Absolute, the messianic Kingdom of Israel:

The dynamic combination of the three following revolutions: a) the evacuation of the entire Diaspora and the return to the Land of Israel of the entire Jewish people, which is one people by will or by force, by consciousness or by compulsion, by own decision or by the decision of the Gentiles; b) the liberation of the entire Land of Israel in the borders of the godly promise which are its geopolitical boundaries, from the Euphrates to the Nile; c) the return by renewal and renaissance to the basic values of Judaism ... these three we call the Kingdom of Israel. ${ }^{51}$

Eldad's Zionism belongs therefore to the 'fundamentalist' variety. By this he reminds us again of pre-1939 Ratosh, with one significant difference: the latter, though also a firm believer in historical determinism, viewed it through strictly secular-materialist lenses. Moreover, Eldad is not content with a mere return to the 'original' Zionism: as we shall see, he wants to transgress Zionism in order to realize what can only be described as an ultra-Zionist theo-political vision.

Understandably, any aspect of Jewish politics which does not conform to Eldad's deterministic philosophy of history is denounced by him as a treachery of the Jewish purpose (in Eldad's words: 'Satan dresses up in many ways. Sometimes he even pretends to be a Zionist or a Zionist leader or an Israeli minister'52). Eldad basically wishes to defend his image of Herzlian Zionism from Herzl's 'unworthy' successors, thus excluding from 'true' Zionism the entire institutional Zionist movement, leaving only the LEHI as the single power striving to realize the Zionist-Messianic vision of Gathering the Exiles in the Kingdom of Israel. In his series of articles 'Foundation stones', published in 1943, while still in the underground, Eldad mounts a fierce attack not only on the policy of the Labour and Revisionist Zionism, but also on their basic principles, calling for a creation of a 'liberation movement on new foundations' ${ }^{53} \mathrm{He}$ writes off the preceding four decades of Zionism, accusing it of philanthropic inclinations to solve the universal 'Jewish problem' instead of serving the positive-internal impulse of the Jews to regain their homeland and establish a kingdom there, which would usher in the messianic age. 'Zionism turned from messianic yearnings for a Davidic kingdom to a refugee question', ${ }^{54}$ which, as Eldad notes, can be solved more effectively elsewhere than in the Land of Israel (though only temporarily due to the 'iron law of the Diaspora' cited above). By making Zionist secularpolitical aims a purpose in itself rather than using them as tools supporting the drive towards the Eldadian concept of redemption, that is, choosing the 'negative' motivation over the 'positive' one, the Zionist movement, Eldad continues, committed two fatal errors: it looked constantly to excuse itself as a servant of humanitarian ends, thus reneging on its national-sovereign nature; 55 by treating the Land of Israel as simply the best place to solve

\footnotetext{
${ }^{50}$ Ibid., 14 (emphasis in the original).

${ }^{51}$ Ibid., 22 (emphases in the original).

${ }_{52}$ Israel Eldad, 'Musaf velo Sof Davar', in Bareli and Ginossar, Tziyonut: Pulmus ben Zmanenu, 470.

${ }^{53}$ Eldad, 'Avnei Yesod', 453.

54 Ibid., 454.

${ }_{55}$ Eldad openly ridiculed mainstream Zionism's dilemmas regarding its treatment of the Palestinian Arabs, since for him it was obvious that the realization of Zionism necessitated the Arabs' dispossession. Eldad, "Yemin" u“smol"', 109.
} 
the global 'Jewish problem', Zionism broke its commitment to it as the Jews' homeland and domain of their kingdom. In effect, Eldad argues, the Zionist movement adopted a 'colonizing' approach to the Land, which pushed it into an unholy alliance with the British (and when the moment came to confront Britain in the 1930s, Eldad adds, the Zionist leadership refused to fulfil its historical role and fatally delayed the emergence of Israel, allowing the destruction of the European Jewry by Hitler). ${ }^{56}$ Contravening the Hegelian logic of Jewish history formulated by Eldad, the Zionist movement made itself illegitimate; hence his call for a new liberation movement, of which the LEHI, it must be assumed, will be the core. This is how Eldad sums up his alternative view of Zionism:

The formulation of the aim of Zionism should have expressed the nation's plain and positive wish: the renewal of the Kingdom of Israel. Any other argumentation weakens the matter and lays it to rest. This is the nation's will. A solution to a problem, anti-Semitism, emigration, etc., all these are side-questions which may be helpful tactically, but the initial declaration from the very first moment should have been clear, like the Frenchman who does not need to base his demand for France on a 'French problem', but on the sovereign will of the French nation. Our dispersal argument was turned upside down. The truth is: not because we are dispersed we want the state but in spite of our dispersal we desire it ... We wish and we fight for a Kingdom whether there is anti-Semitism or not, whether there is a problem or not, whether there are refugees or not. ${ }^{57}$

What do the Poles, the French, the Greeks fight for? To solve the Polish, Greek, French problem? No! They fight for the liberation of their homeland and its independence as a selfsufficient cultural aim and not because it would solve any problem. Thus, and not otherwise, we ought to have presented the question. Not an establishment of a safe haven, but the liberation of the homeland. Not a solution to the problem of the people, but to the problem of the land. ${ }^{58}$

The principles which 'political Zionism' and 'practical Zionism' subscribed to were two: the Hebrew people as an object, an international problem. The Land of Israel as a country to be colonized, and these two were behind Zionism's failure. ${ }^{59}$

We are convinced that a major cause for the lack of Zionist success must be attributed to the fact that it touched only the shell. [It did not touch] the deepest string in the Jewish soul, the messianic string ... Therefore it became a movement of colonization, of funds and statistics. ${ }^{60}$

Consequently, Eldad argues, the Zionist movement adopted values at odds with the Jewish messianic imperative, like 'normalization' and 'productivization', which for him are an expression of the Diasporic desire to assimilate, that is, to 'become a people like all peoples'. Likewise, Zionists accepted the international community's diplomatic rules instead of forcing upon it rules of their own, and adopted liberal-parliamentarian methods of managing their politics (which Eldad ridicules as 'mathematical Zionism'), as if the core values of Judaism could be put to vote. His conclusion is that secular Zionism sowed the seeds of its own destruction by turning away from Jewish religious values. This legitimized

\footnotetext{
${ }^{56}$ Eldad, 'Avnei Yesod', 453-8; Eldad, 'Medinat Israel', 12-3; Eldad interview, 438-43; Eldad, 'Musaf', 469-71.

${ }_{57}$ Eldad, 'Avnei Yesod', 455 (emphases in the original).

${ }^{58}$ Ibid., 456.

${ }^{59}$ Ibid., 459 (emphases in the original).

${ }^{60}$ Ibid., 464.
} 
possible de-Zionisation (once a contradiction between democratic values and Jewish nationalism is apprehended) leading to the eventual disestablishment of the state of Israel. ${ }^{61}$ Eldad accordingly declares that

There are values which can never be measured mathematically; ... We shall not go to elections, shall not conduct voting, shall not ask the majority. We deal not with atoms. We represent the most vital power of the people, we represent the loftiest cultural and national urge, which is to create a kingdom worthy of a nation like our own ... We express the best national yearnings, the desire for the Messiah which is a redemption from exile, but much more than that, more positive, more cultural. And we do not ask the assimilated rabbi in America and the 'progressive' from Hashomer Hatzair [a youth socialist-Zionist movement] here in the land whether he wants the Kingdom of Israel or not, like Spartacus who did not ask the slaves, like Piłsudski who did not ask, like De-Gaulle who does not ask. ${ }^{62}$

We can discern in Eldad's rhetoric the cult of the chosen few, who 'drag' the nation to the fulfilment of its historic purpose, despite the indifference or the hostility of the many. The national avant-garde, though numerically a minority is in fact a majority in the eyes of history, Eldad explains, since it is conscious of history's immanent rules. Moreover, unwillingness to 'push' the majority to redemption due to democratic considerations is condemned by Eldad as a crime against nation and history. ${ }^{63}$

After 1948 Eldad transferred his anti-democratic principles to the state of Israel. Regarding the state as an incomplete fulfilment of the redemptory purpose, he could not agree to parliamentary democracy which, at least potentially, could vote away the finite Zionist goal of establishing the Kingdom of Israel in biblical borders. And indeed Eldad stated openly that 'democracy must be limited by Zionism'64 and expressed his ire with Israeli leaders who refused to speak 'the truth' about Israeli desire for territorial expansion (which was paradoxically left to be 'unmasked' by Israel's Arab enemies) and accepted the legitimacy of the existing neighbouring Arab states. ${ }^{65}$

Eldad stressed that the existence of Israel in its 1948 borders is acceptable only inasmuch as it serves as a tool or a 'beachhead' for the establishment of the Jewish messianic Kingdom; therefore, if Israeli policy is concentrated on maintaining the state for its own purpose, it will be illegitimate and the state will become unviable. As long as the Kingdom has not come into existence the purpose of Zionism according to Eldad has not been accomplished, hence the post-1948 and even post-1967 boundaries can be only temporary, since to accede to them would violate the determinist laws of Jewish history. For Eldad the state of Israel is not synonymous with the Land of Israel, thus, the aspiration to make the two one by stretching the State all over the Land is the long-term goal of Eldad's ultra-Zionism, which transgresses the 'limited' and therefore unsustainable ends of non-messianic Zionism: 'If there is a place for disappointment ... it is from Zionism ... which did not realize its responsibility for what is due to happen in the Diaspora on the

\footnotetext{
${ }^{61}$ Ibid., 458-63; Eldad interview, 451; Eldad, 'Medinat Israel', 12, 19-21; Eldad, 'Musaf', 469-70

${ }^{62}$ Eldad, 'Avnei Yesod', 463, 464.

${ }^{63}$ Ibid., 462-5; Eldad, 'Medinat Israel', 10, 12-13, 16.

${ }^{64}$ Eldad, "'Yemin" u"smol”, 108.

${ }^{65}$ Eldad, 'Medinat Israel', 17-19.
} 
one hand and the power stored in the people on the other hand. And I do not refer here to the past only, but to the present and the future as well'. ${ }^{66}$

In considering Zionism a kind of 'never-ending story' Eldad showed himself to be largely still a disciple of Zeev Jabotinsky. Jabotinsky promulgated the idea of 'monism', whereby the period leading up to the establishment of the Jewish state must not suffer from any ideological and political ambivalence or duality (condemning the mixture of socialism and Zionism practiced by the Labour Zionist camp); rather, all efforts, intellectual, political and diplomatic, must be bent on the attainment of a Jewish majority in Palestine as a precondition for the establishment of a Jewish state by democratic means. Once the state is established, Jabotinsky continued, there will be room for various experiments to forge the best social system for the sovereign Jewish people. ${ }^{67}$

Eldad raised Jabotinsky's principle of monism to a higher level by asserting that as long as the Kingdom of Israel is not established, the monist discipline must be strictly observed, despite the existence of a sovereign Israel. Therefore, Israel's socio-political structure is conditioned upon its adherence to Jewish historical determinism, making 'secondary ideas such as issues of regime ... democracy or acknowledgment of the Arabs' equality (and each of them is a value per se and I do not negate them)' 68 shifting values. Eldad explains further: 'inasmuch as this regime and this state create the conditions, or the springing board, or the beachhead for the realization of the vision, which is a historical and national necessity, they shall be deemed good; ... [A true Jewish leadership] must declare as the highest priority of the state of Israel the Redemption and the Messianic Vision ... A state of Israel which does not succumb to this law as its supreme law and shall not subordinate all other interests to this supreme aim will be an illegal state both religiously and historically' ${ }^{69}$ For this purpose a revolution must take place, which would sweep away the leadership unfaithful to the laws of Jewish historical dialectics and bring to power a new ultra-Zionist leadership with an articulated consciousness of its historical role and duty.

\section{Conclusion}

We have reviewed two cases of gradual radicalization within the Zionist movement motivated by the growing tension between the Zionist leadership and the British Mandate authorities in the 1930s-1940s. The path chosen by Yonatan Ratosh and Israel Eldad led from 'fundamentalist' Zionism to an opposition to the British presence in Palestine and the demand for its termination, to a dissatisfaction with the Zionist leadership which did not accede to this demand, and finally, to a rejection of Zionism once the Zionist policy at the time was redefined as inherent to Zionist ideology. With a new adversary identified, the British became a secondary element for Ratosh and Eldad.

Despite their shared background and line of thought, there remained a significant difference between the two, which resulted in the emergence of two hostile camps on the margins of Israeli political life: the staunchly nationalist-secular 'Canaanism' which

\footnotetext{
${ }^{66}$ Eldad, 'Musaf', 467 (emphasis mine).

${ }_{67}$ Bilski Ben-Hur, Kol Yakhid Hu Melekh, 227-334.

${ }^{68}$ Eldad, “Yemin" u“smol"', 107 (emphasis mine).

${ }^{69}$ Eldad, 'Medinat Israel', 15, 22. See also ibid., 11, 16-19, 22; Eldad, 'Musaf', 465-72.
} 
adopted many leftist elements on the one hand, and the religious-messianic Zionism on the other hand, represented by the right-wing Bloc of the Faithful ('Gush Emunim') movement since the 1970s. While Ratosh derided Eldad's post-1948 periodic Sulam as a 'Jewish study-house',70 Eldad called his ideology a 'futile chatter of assimilated Canaanites and "Israelis" ... who create an "Israeli" ideology of separation from the Jewish people', 71 insisting that "a "Diasporic" Jew living in the Land and obeying all his religious duties is much more Israeli than a "Sabra" imitating a Parisian drawing, an American actress or a Russian poem' ${ }^{72}$

It is this article's contention that this difference originates in the intellectually distinct paths of Ratosh's and Eldad's development. Ratosh broke with Zionism when he adopted Horon's historiography which contradicted the Jewish one (transposed to Zionism nearly unscathed, only that the mythical figure of the Messiah was substituted by a human agent), and used it to construct a national-liberal ideology which opposed Zionism due to what it perceived as its primordial and illiberal characteristics. Having denied the Jews the right for national self-determination, the 'Canaanites' declared themselves to be speaking in the name of an entirely different Hebrew nation, which was conceived in a liberal-secular framework with no racial undertones. The 'Canaanites' were not busy with rethinking Zionism; they rejected it out of hand as an 'impostor' of a 'true' nationalism (though not denying their own Zionist past $\left.{ }^{73}\right)$.

Contrariwise, Israel Eldad, who did not doubt Jewish-Zionist historiography, remained essentially a Zionist. His novelty lay elsewhere: in a radical re-conceptualization of Zionism in messianic Hegelian terms. As a result, he denied the validity of the entire Zionist movement, except for the LEHI and the Bloc of the Faithful, since only these were 'obedient' to his deterministic laws of Jewish history. ${ }^{74}$ Hence, Eldad's fierce opposition to what he titled 'Zionism' was not directed at the ideology in total (in the fashion of Ratosh), but only at the guiding principles of secular Zionism. This is why Eldad's transformation is a transition from 'fundamentalist' Zionism to 'ultra-Zionism'. Ultimately, it would seem that Ratosh pursued a longer and much bolder way than Eldad, paying a higher price, politically as well as personally, remaining an outcast in Israeli literature and politics almost till the end of his life.

The difference between the two thinkers is evident even when they use similar arguments against Zionism. We have seen above that both identified Zionism with Judaism; however, whereas for Ratosh this was Zionism's source of weakness, for Eldad it was the potential source of its strength. And whereas Ratosh accused Zionism of upholding 'anti-national' Jewish values, Eldad accused it of the opposite - of abandoning the 'eternal' and 'essential' Jewish national aim of working for messianic redemption. Finally, using the 'Hebrew' denominator, Ratosh and Eldad invested in it different meanings: when Ratosh spoke of a 'Hebrew nation' he meant an autochthonous territorial-linguistic nation whose

\footnotetext{
70 Yonatan Ratosh, 'Naara shenishbeta', in Ratosh, Sifrut Yehudit, 73.

71 Eldad, 'Medinat Israel', 16, 19.

72 Ibid., 21.

73 Ratosh, Reshit hayamim, 169-70.

${ }_{74}$ For the debate within the Zionist ranks regarding Zionism's relation to various manifestations of the Jewish messianic idea, see Shmuel Almog, Zionism and History: The Rise of a New Jewish Consciousness (New York, Jerusalem: St. Martin's Press \& Magnes Press, 1987), 58-66.
} 
bonds to the Jews were to be exclusively genetic, but not social or cultural; ${ }^{75}$ Eldad, conversely, wrote of the 'Hebrew revolution' as of the creation of a 'new Jew', that is, in an essentially Zionist way.

We must not, however, identify indiscriminately the views expressed by Ratosh and Eldad with the platforms of the movements they led. Both the 'Canaanites' and the LEHI were complex phenomena which contained manifold strands of thought, and their ideology and politics converged at several points. Ratosh's 1938 booklet We Aspire to Power was one of the impulses for the emergence of the LEHI in 1940, ${ }^{76}$ though its founder Avraham Stern rejected Ratosh's views regarding Judaism and Jewish heritage and framed his struggle in Jewish-messianic terms. ${ }^{77}$ When Ratosh adopted 'Canaanism', the breach between him and the LEHI grew deeper, as is evidenced by Ratosh's derisive references to the LEHI in 'The Opening Discourse'. However, Joseph Heller reminds us that after 1944 a pro-Soviet wing grew in significance within the LEHI, which resulted in a marginalization of the messianic Stern-Eldad tendency and a renewed growth in the pro'Canaanite' tendencies. ${ }^{78}$ Besides this principal affinity, the two groups also mixed personally, since some prominent 'Canaanites' joined the LEHI, attracted by its antiBritish radicalism, opposition to Zionist mainstream and subscription to the idea of cultural and political primacy of Palestinian Hebrews over the Diaspora Jews (that is, the 'positive' aspect of Zionism). One of the LEHI 'Canaanites' was Eliyahu Beth-Tzuri, who was hanged in Cairo in 1945 for his part in the assassination of the British minister of state in the Near East, Lord Moyne. He delivered at his process a fiery 'Canaanite' speech, declaring that 'my ideas are not Zionist ideas. We don't fight to uphold the Balfour Declaration. We don't fight for the sake of the National Home. We fight for our freedom. In our country a foreign power rules'. ${ }^{79}$ Beth-Tzuri, however, was dissatisfied with Ratosh's intellectualism and his reluctance to face the British as long as the Hebrew youth

\footnotetext{
${ }^{75}$ It is important to realize that the 'Canaanites' did not deny that they hailed from the Jews, whom they considered a mixed array of communities of various ethnic origins united only by religious tradition (for the 'Canaanite' version of the emergence of Judaism and Jews, see Horon, Kedem vaerev, 329-45), but refused to accede for the application of pre-modern criteria of identity to the modern Hebrew nation, which in their opinion Zionism aimed at. Hence the declaration by Ratosh's youngest brother Uzzi Ornan (a professor of linguistics at the Technion) that 'my father was a Jew, but I am not; there is no contradiction here'. 'Anakhnu Knaanim: Sikhot im Prof. Uzzi Ornan', Svivot (December 1994), 66. For more on Ratosh's concept of nation-formation, see Yonatan Ratosh, 'Huledet haumma', in Ratosh, Reshit hayamim, 38-41.

${ }^{76}$ This is confirmed also by LEHI co-leaders Nathan Yalin-Mor (Yalin-Mor, Lohamey Herut Israel, 56, 60) and Yitzhak Shamir (Porat, Shelah veet beyado, 104-5).

${ }^{77}$ For more on Ratosh-Stern relations, see Heller, 'The Zionist Right and National Liberation', 93; Porat, Shelah veet beyado, 204-23.

${ }^{78}$ Heller, 'The Zionist Right and National Liberation', 88, 104-5. On the 'leftist' tendency in the LEHI that advocated relying on the USSR in an anti-imperialist struggle in which the Arabs of Palestine and the entire Middle East could partake (and which went as far as incorporating some Marxist principles into the LEHI ideology), see Isabella Ginor and Gideon Remez, 'A Cold War Casualty in Jerusalem, 1948: The Assassination of Witold Hulanicki', Israel Journal of Foreign Affairs 4:3 (2010): 135-56; Yalin-Mor, Lohamey Herut Israel, 170, 180-1, 344-55, 381-95, 407-8, 412-3, 419-33, 438-9, 457-61. We must keep in mind, however, that there is no principal parallel between 'Canaanism' and a pro-Soviet stance. The pro-Soviet LEHI members were attracted to 'Canaanism' due to its national-liberation tones, and not due to its (nonexistent) socialist inclinations. Yalin-Mor, who came to head the pro-Soviet LEHI wing, had severe reservations regarding the 'Canaanite' ideology, though he admits that in many respects he could not but agree with it (ibid., 146-7).

${ }_{79}$ Cited in Diamond, Homeland or Holy Land?, 150, n. 77. See also Porat, Shelah veet beyado, 222; Yalin-Mor, Lohamey Herut Israel, 147, 191, 210-26, 248-59; and the booklet Hahitnakshut baLord Moyne (Tel Aviv: Hamidrasha haleumit, 1975), which was published on the occasion of Beth-Tzuri's (and his fellow assassin, Eliyahu Hakim's) reburial in Israel by the heirs of the rightist LEHI wing, who were apparently troubled by Beth-Tzuri's anti-Zionism and atheism and tried to play it down.
} 
was held 'captive' by the Zionist ideology, stating 'I am with you in all respects, but bombs should be thrown as well'. 80

To sum up, 'Canaanism' and Eldad's messianism ultimately represented entirely different, and even contradictory, national visions: one Hebrew anti-Zionist, the other Jewish ultraZionist. One might argue that 'Canaanism's' liberal nationalism combined with opposition to Zionism gave rise to the post-Zionist standpoint which became popular in Israel since the late $1980 \mathrm{~s}^{81}$ and which Eldad wholeheartedly despised. ${ }^{82}$ His own ideology was illiberal to the core, mixing perennialist conceptions of national identity (the Jewish people as eternal and unchangeable), religious radicalism and a cult of the soil. ${ }^{83}$ This latter characteristic, curiously, brought some observers of the Israeli public life to term the Bloc of the Faithful ideology 'Messianic neo-Canaanism', 84 assuming (somewhat short-sightedly) that at the core of 'Canaanism' lay the land and not the nation. However, what the comparative analysis of 'Ratoshism' and 'Eldadism' shows above all is that Israeli antiZionism can assume at times an extreme nationalist shape.

\section{BIBLIOGRAPHY}

Almog, Shmuel. Zionism and History: The Rise of a New Jewish Consciousness. New York, Jerusalem: St. Martin's Press \& Magnes Press, 1987.

Arnow, David. 'The Holocaust and the Birth of Israel'. Journal of Israeli History: Politics, Society, Culture 15:3 (1994): 257-81.

Ben-Hur, Raphaella Bilski. Kol Yakhid Hu Melekh: hamakhshava hakhevratit vehamdinit shel Zeev Jabotinsky. Tel Aviv: Dvir, 1988.

${ }^{80}$ Porat, Shelah veet beyado, 218. Other LEHI 'Canaanites' were Ratosh's brother Gamliel Heilperin who trained Beth-Tzuri in the underground (later a professor of Semitic philology at the University of Pennsylvania, who signed his works as Svi Rin [Yalin-Mor, Lohamey Herut Israel, 190, 255]) and Boas Evron and Amos Keinan (later prominent public intellectuals of the Israeli radical left [ibid., 361-5]).

81 On post-Zionism, see Ephraim Nimni, ed., The Challenge of Post-Zionism: Alternatives to Israeli Fundamentalist Politics (London, New York: Zed Books, 2003); Laurence J. Silberstein, The Postzionism Debates: Knowledge and Power in Israeli Culture (New York, London: Routledge, 1999). These books are sympathetic to post-Zionism. A critical treatment is offered in Tuvia Friling, ed., Tshuva leamit post-tziyoni (Tel Aviv: Yediot Aharonot, 2003). A balanced collection, bringing under the same covers both supporters and opponents of post-Zionism, is Anita Shapira and Derek J. Penslar, eds., Israeli Historical Revisionism: From Left to Right (London, Portland: Frank Cass, 2003).

82 Eldad interview, 451

83 Notably, Yalin-Mor portrayed Eldad in his memoirs as somewhat less dogmatic: he affirms democratic principles (Yalin-Mor, Lohamey Herut Israel, 433), opposes the idea of the expulsion of Palestinian Arabs (ibid., 359) and is indignant over the Deir-Yassin massacre (on $9^{\text {th }}$ of April 1948 a joint battalion of ETZEL and LEHI attacked the Palestinian village of Deir-Yassin on the western outskirts of Jerusalem and massacred its inhabitants. See ibid., 469-73). It is not clear whether Eldad himself chose afterwards to obfuscate his earlier beliefs or whether it was Yalin-Mor's attempt at a hindsight polemic with his fellow LEHI co-leader (a deeper analysis of LEHI's ideological intricacies is outside the scope of this article, but it is beyond doubt that there was a strong political and personal disagreement between Eldad and Yalin-Mor. See ibid., 139-40, 264, 358-60). Yalin-Mor asserted furthermore that Avraham Stern actually rejected Eldad's messianic radicalism and attributes the idea popular in some LEHI circles that the former became a religious fanatic under the latter's influence to a 'misunderstanding' (ibid., 140). This argument is supported by Boas Evron, who wrote that by the time he joined the LEHI the movement's founding manifesto (co-authored by Stern and Eldad) had been all but forgotten due to LEHI's more recent pro-Soviet turn. Boas Evron, 'Hama'ase - uvavuato ha'akademit', Yediot Aharonot 2.3.1984: 20. However, as an ironic characteristic of the LEHI by another 'Canaanite' ('a cocktail of Rabbi Kook [the founder of religious Zionism] and Karl Marx'. Porat, Shelah veet beyado, 221) shows, LEHI’s original principles were never entirely abandoned.

${ }^{84}$ David Ohana, Lo knaanim, lo tzalbanim: Mekorot hamitologia haisraelit (Jerusalem: Keter, 2008), 31, 210-11, 228, 285. 
Bareli, Avi, and Pinchas Ginossar, eds., Tziyonut: Pulmus ben Zmanenu - Gishot Mekhkariyot veideologiyot. Sde Boker: Ben-Gurion University, 1996.

Diamond, James S. Homeland or Holy Land? The 'Canaanite' Critique of Israel. Bloomington, Indianapolis: Indiana University Press, 1986.

Eldad, Israel. 'Avnei Yesod'. In Bareli and Ginossar, Tziyonut: Pulmus ben Zmanenu - Gishot Mekhkariyot veideologiyot, 453-65.

—_. An interview with Israel Eldad. In Bareli and Ginossar, Tziyonut: Pulmus ben Zmanenu - Gishot Mekhkariyot veideologiyot, 437-53.

___. 'Medinat Israel kerosh-gesher lemalkhut Israel'. Sulam 10:1 (1958): 10-23.

'Musaf velo Sof Davar'. In Bareli and Ginossar, Tziyonut: Pulmus ben Zmanenu Gishot Mekhkariyot veideologiyot, 465-72.

“"Yemin" u“smol” batziyonut', interview by Michael Sashar, Kivunim 1:38, new series (March 1990): 107-17.

Evron, Boas. 'Hama'ase - uvavuato ha'akademit'. Yediot Aharonot, 2 March 1984, 20-1.

Friesel, Evyatar. 'On the Myth of the Connection between the Holocaust and the Creation of Israel'. Israel Affairs 14:3 (2008): 446-66.

Friling, Tuvia, ed., Tshuva leamit post-tziyoni. Tel Aviv: Yediot Aharonot, 2003.

Ginor, Isabella, and Gideon Remez. 'A Cold War Casualty in Jerusalem, 1948: The Assassination of Witold Hulanicki'. Israel Journal of Foreign Affairs 4:3 (2010): 13556.

Heller, Joseph. 'The Zionist Right and National Liberation: from Jabotinsky to Avraham Stern'. Israel Affairs 1:3 (1995): 85-109.

Hofmann, Klaus. 'Canaanism'. Middle Eastern Studies 47:2 (March 2011): 273-94.

G. Horon, Adolphe. 'Canaan and the Aegean Sea: Greco-Phoenician Origins Reviewed'. Diogenes 58 (1967): 37-61.

—. Eretz-Hakedem: Madrikh Histori umdini lamizrakh Hakarov. Tel Aviv: Hermon, 1970.

- Kedem vaerev: Knaan - Toldot Eretz ha'ivrim. Tel Aviv: Dvir, 2000.

Kaplan, Eran. The Jewish Radical Right: Revisionist Zionism and its Ideological Legacy. Madison: University of Wisconsin Press, 2005.

Keinan, Amos. 'Vehaknaani az baaretz'. Proza, 17-18 August-September 1977, 4-13.

Nimni, Ephraim, ed., The Challenge of Post-Zionism: Alternatives to Israeli Fundamentalist Politics. London, New York: Zed Books, 2003.

Ohana, David. Lo knaanim, lo tzalbanim: Mekorot hamitologia haisraelit. Jerusalem: Keter, 2008.

Ornan, Uzzi. ‘Anakhnu Knaanim: Sikhot im Prof. Uzzi Ornan'. Svivot (December 1994): 61-73.

Porat, Yehoshua. Shelah veet beyado: Sipur Khayav shel Uriel Shelah (Yonatan Ratosh). Tel Aviv: Makhbarot lesifrut, 1989.

Ratosh, Yonatan. 'Hakdama'. In Reshit hayamim: Ptikhot 'Iuriyot, 7-31. Tel Aviv: Hadar, 1982.

—_. 'Huledet haumma'. In Reshit hayamim: Ptikhot 'Ivriyot, 38-41. Tel Aviv: Hadar, 1982.

— - 'Naara shenishbeta'. In Sifrut Yehudit balashon haivrit: Ptikhot bevikoret uviv'ayot halashon, 71-3. Tel Aviv: Hadar, 1982.

—. Reshit hayamim: Ptikhot 'Ivriyot. Tel Aviv: Hadar, 1982. 
—_ Sifrut Yehudit balashon haivrit: Ptikhot bevikoret uviv'ayot halashon. Tel Aviv: Hadar, 1982.

Scholem, Gerschom. 'Hatziyonut - Dialektika shel Retzifut umered'. In Ein Shaananim betziyon: Sikhot al Mekhir hatziyonut, edited by Ehud Ben-Ezer, 287-317. Tel Aviv: Am Oved, 1986.

Shapira, Anita, and Derek J. Penslar, eds., Israeli Historical Revisionism: From Left to Right. London, Portland: Frank Cass, 2003.

Silberstein, Laurence J. The Postzionism Debates: Knowledge and Power in Israeli Culture. New York, London: Routledge, 1999.

Spielman, Anschel, ed., Hahitnakshut baLord Moyne. Tel Aviv: Hamidrasha haleumit, 1975.

Tamir, Dan. "'Dictate more, for we should obey your orders!" Cult of the Leader in InterWar Hebrew Fascism'. Politics, Religion E Ideology 14:4 (2013): 449-67.

—_. 'Some Thoughts about Hebrew Fascism in Inter-War Palestine'. Zeitschrift für Religions- und Geistesgeschichte 63:4 (2011): 364-81.

Vital, David. 'Zionism as Revolution? Zionism as Rebellion?'. Modern Judaism 18 (1998): 205-15.

Yalin-Mor, Nathan. Lohamey Herut Israel: Anashim, Re'ayonot, 'Alilot. Jerusalem: Shikmona, 1975 .

Zerubavel, Yael. Recovered Roots: Collective Memory and the Making of Israeli National Tradition. Chicago, London: The University of Chicago Press, 1995.

Zouplna, Jan. 'The Evolution of a Concept: The Relationship between State and Religion in the Thought of Vladimir Jabotinsky, 1919-1940'. Journal of Modern Jewish Studies 4:1 (2005): 13-31. 